\title{
Analysis of Erythrocyte Indices of Children in Internally Displaced People Camp of Yola, Northeast Nigeria
}

\author{
Emmanuel Asuquo Etim ${ }^{*}$, Akpan Akaniyene Udokang ${ }^{1}$, Adjekuko Ohwonigho Collins ${ }^{2}$ and Obeagu \\ Emmanuel Ifeanyi ${ }^{3}$
}

${ }^{1}$ Laboratory Department, Federal Medical Centre, Yola, Adamawa State, Nigeria

${ }^{2}$ Department of Medical Laboratory Services, General Hospital Okwe-Asaba, Delta State, Nigeria

${ }^{3}$ Diagnostic Laboratory Unit, Department of University Health Services, Micheal Okpara University, Abia State, Nigeria

*Corresponding author: Emmanuel Asuquo Etim, Laboratory Department, Federal Medical Centre, Yola, Adamawa State, Northeast Nigeria, Tel: +2348063924735; Email: emmasuti@yahoo.com

\begin{abstract}
Background/Objectives: Erythrocyte indices constitute important parameters useful in clinical care of children. Analysis of erythrocyte indices for children in IDP (Internally Displaced People) camps in Adamawa State like in most states in Nigeria was not fully studied. Therefore, this study aims to analyze the erythrocyte indices of children in Fufore IDP camp in Yola.

Materials and Methods: This study enrolled 297 children (137 females and 160 males) in the camp with age range of 12 to 61 months old and 201 apparently healthy school children as control group. $3 \mathrm{ml}$ of blood were collected from children and transferred into K3-EDTA vacutainer tubes. Full blood count was determined within four hours of blood collection using the Sysmex XP300 hematological analyzer.

Results: Mean erythrocyte count of subjects and control was $3.1 \pm 0.7 \mathrm{X109//}$ and $4.3 \pm 0.7 \mathrm{X109//}$ respectively at $\mathrm{P}<0.05$ and red cell distribution width (RDW) of subjects was $16.9 \%$ while that of control was $13.5 \%$. Hemoglobin level of subject and control was $9.7 \pm 1.1 \mathrm{~g} / \mathrm{dl}$ and $12.4 \pm 1.3 \mathrm{~g} / \mathrm{dl}$ respectively. The mean Pack Cell Volume (PCV) of subjects was $32.7 \pm 0.3 \%$ while the PCV of control group was $37.0 \pm 0.2 \%$. The Mean Cell Volume (MCV) of subject and control group was $74.8 \pm 0.6$ fl and $81 \pm 0.5 \mathrm{fl}$ respectively while Mean Cell Hemoglobin $(\mathrm{MCH})$ of the control and subject group was $26.9 \pm 0.9 \mathrm{pg}$ and 27 \pm 0.4 pg respectively at $\mathbf{P}<0.05$.

Conclusion: Children in IDP camp had lower RBC count, PCV, MCV, Hemoglobin values and higher RDW value than the control group at $\mathbf{P}<\mathbf{0 . 0 5}$. Hence microcytic and iron deficiency anemia was observed among children in Fufore IDP camp in Yola.
\end{abstract}

Keywords: Red cell indices; Infant; IDP camp

Received Date: March 07, 2019; Accepted Date: April 01, 2019; Published Date: April 08, 2019

Citation: Emmanuel Asuquo Etim, Analysis of Erythrocyte Indices of Children in Internally Displaced People Camp of Yola, Northeast Nigeria. J Clin Cases Rep 2(3): 69-75. DOI: https://doi.org/10.46619/joccr.2019.2-1042

(C) 2019 Tridha Scholars 


\section{Introduction}

Erythrocyte indices constitute important parameters useful in clinical care of children [1] and red cell indices are part of routine automated full blood count test which measures our general health. Red cell indices also examine red cell conditions and measures the size, shape, and physical characteristics of our red blood cells [2]. However, RBC indices are laboratory parameters that are frequently overlooked in clinical practice but they provide assistance in establishing diagnosis in inflammatory [3] and anemic patients [4]. Red cell indices consider in this study are: RDW (Red Cell Distribution Width), MCV (Mean Cell Volume), MCH (Mean Cell Hemoglobin), MCHC (Mean Cell Hemoglobin Concentration). MCV is a measurement of the average size of red blood cell and $\mathrm{MCH}$ is a calculation of the average amount of hemoglobin inside a red blood cell, while MCHC is a measurement of the average concentration of hemoglobin inside a red blood cell and Red Cell Distribution Width (RDW) is an automated measure of the variation in red blood cell sizes. Red blood cell (RBC) count and packed cell volume (PCV) of infants were also estimated and the clinical implications of determining the red cell indices along with the RBC count and PCV are that various type of anemia can be detected, identify and differentiated in infant [1].

Internally Displace People (IDP) camps in Yola are settlement sites set aside for people whose houses and properties have been destroyed by chronic humanitarian crisis, arising from insurgency, counter-insurgency, inter and intra communal fights. The deteriorating security situation in and around villages of Adamawa State, coupled with a relatively more stable situation in Yola, has culminated into a large number of displaced individuals fleeing into Yola to seek refuge. According to International Organization for Migration (IOM) Displacement Tracking Matrix (IOM-DTM) program, in 2015 Adamawa State had the second highest number of IDPs of 113,437 people behind Borno state in Nigeria. The 2014 IOM report also indicates that there are 15,317 households living in displacement sites in Adamawa state and $81.3 \%$ of the IDP population comes from local communities of Gwoza, Askira-Uba, Baza, Lassa, Biu, Michika, Madagali, Mubi North, Mubi South, Hong, Gombi among others, and since 2013 over $45 \%$ of these persons have been internally displaced more than twice [5,6]. Currently there are over 19 IDP camps in Adamawa state including Fufore camp which houses about one thousand people with over five hundred children as at 2016 and the 2015 IOM-Displacement Tracking Matrix (DTM) project assessments of displacement site indicates that $52 \%$ of population in these IDP camps are female while $48 \%$ are male and Half of the total number of individuals residing in camp are children [7]. Teenage-girls, breastfeeding mothers, pregnant women, unaccompanied and separated children are still considered as the most vulnerable group in IDP camps [7]. Children in IDP camps are more prone to risk of becoming anemic due to poor living conditions occasion by limited access to food, health care and direct exposure to disease [8]. Childhood are characterized by dynamic period of growth and development in individual and this period of life usually require special healthcare and hematological considerations [9] hence, the analysis of red cell indices of children in IDP camp becomes essential to elucidate the general health and anemic status of children in Fufore camp. In addition, the present and/or absent of anemia and the red cell indices analysis for infant in IDP camps in Adamawa State like in most states of Nigeria have not been fully studied and this is manifested in a dearth of studies on erythrocyte indices in African children [1], these therefore, were the impetus for which this present study was carried out. It is believed that information obtained from this study will enhance adequate understanding of the healthcare need and anemic status of infant in IDP camps in Yola so as to improve health intervention and help government policies formulations for this set of children in Nigeria.

\section{Inclusion Criteria}

Children of 12 to 61 months old who has spent a minimum of three weeks in Fufore IDP camp were recruited for this study. 


\section{Exclusion Criteria}

Children of the age range of 12 to 61 months who has spent less than three weeks in camp and children above 61 months of age were excluded from this study.

\section{Material and Method}

A cross-sectional study was conducted among children in Fufore internally displace people camp (IDP) in Yola town Northeastern Nigeria in 2016. Study approval was obtained from the management of the camp. The study enrolled 297 infants comprising of 137 females and 160 males with age range of 12 months to 61 months (Table 1 and Table 2) and weight range of $8.0 \mathrm{~kg}$ to $17.9 \mathrm{~kg}$. The sample size was obtained from opportunistic volunteers in the camp and 201 apparently healthy school children of both sexes and age from 12 to 60 months (i.e. 1 to 5 years) were also recruited and used as control group in this study.

\begin{tabular}{|c|c|c|}
\hline Sex of Children & Number Observed & Percentage \\
\hline Males & 137 & $46.13 \%$ \\
\hline Females & 160 & $53.87 \%$ \\
\hline
\end{tabular}

Table 1: Sex distribution of experimental subjects.

\begin{tabular}{|c|c|c|}
\hline Age of children (months) & Number observed & Percentage \\
\hline $12-21$ & 31 & $10.44 \%$ \\
\hline $22-31$ & 55 & $18.52 \%$ \\
\hline $32-41$ & 107 & $36.02 \%$ \\
\hline $42-51$ & 67 & $22.56 \%$ \\
\hline $52-61$ & 37 & $12.46 \%$ \\
\hline
\end{tabular}

Table 2: Sex distribution of experimental subjects.

\section{Sample Collection}

Three $\mathrm{ml}$ of blood were drawn from a convenient peripheral vein of children in the camp and transferred into K3-EDTA vacutainer tubes. The vacuum tubes were labeled with child's number, sex, weight and age. The samples were placed in an insulated cool box, protected from light and further transported to Laboratory Department of federal medical center Yola where Full blood count was determined in the blood within four hours of collection using the Sysmex XP300 hematological analyzer. The values of red cell indices were obtained from the automated full blood count results.

\section{Statistical Analysis}

Statistical analysis was performed using the SPSS computer software version 20.0 (IBM Chicago, IL, USA). Descriptive values were given as mean and standard error of mean. Categorical variables were expressed as the number of cases and the percentage value. The Student's $t$-test was used to compare the means differences of the estimated parameters and all statistics were carried out at the probability level of 0.05 .

\section{Results}

Age distribution was such that subject between 12 to 21 months old made up of 10.44\% (31) of the subject population and $18.52 \%$ (55) of subjects were between 22 to 31 months old. Infant of 32 to 41 months old made up the largest percentage of $36.02 \%$ (107) in the subject population while $22.56 \%$ of the population were between 42 to 51 months old. $12.46 \%$ of infant 
http://www.tridhascholars.org | July-2019

in the study population were 52 to 61 -month old. As indicated in table 2. Males and female made up of $46.13 \%$ and $53.87 \%$ of the subject population respectively as shown in (Table 1).

Analysis of red cell indices of infants in Fufore IDP camp shows that the mean total red cell count of children in camp was $3.1 \pm 0.7 \times 109 / 1$ while that of the control group was $4.3 \pm 0.7 \times 109 / 1$ at $\mathrm{P}<0.05$. In addition, the red cell distribution width coefficient of variation (RDW-CV) of subjects was $16.9 \%$ while the RDW-CV of control was $13.5 \%$. Hemoglobin level of subject and control was $9.7 \pm 1.1 \mathrm{~g} / \mathrm{dl}$ and $12.4 \pm 1.3 \mathrm{~g} / \mathrm{dl}$ respectively. The mean Pack Cell Volume (PCV) of the subjects was $32.7 \pm 0.3 \%$ while the PCV of control group was at $37.0 \pm 0.2 \%$. On the other hand, the Mean Cell Volume (MCV) of the subject was $74.8 \pm 0.6 \mathrm{fl}$ while that of the control group was $81 \pm 0.5 \mathrm{fl}$. Furthermore, Mean Cell Hemoglobin $(\mathrm{MCH})$ of the control and subject group was $26.9 \pm 0.9 \mathrm{pg}$ and $27 \pm 0.4 \mathrm{pg}$ respectively and the value of Mean Cell Hemoglobin Concentration (MCHC) for the subject was $30.6 \pm 0.1 \mathrm{~g} / \mathrm{dl}$ while the MCHC of the control group was $33 \pm 0.2 \mathrm{~g} / \mathrm{dl}$ at $\mathrm{P}<0.05$ as shown in (Table 3).

\begin{tabular}{|c|c|c|c|c|c|c|c|c|}
\hline & $\begin{array}{c}\text { Red cell } \\
\text { count } \\
(\mathbf{X 1 0} / \mathbf{l})\end{array}$ & $\begin{array}{c}\text { RDW- } \\
\mathbf{C V} \\
(\boldsymbol{\%})\end{array}$ & $\begin{array}{c}\text { Hemoglobin } \\
\text { Level }(\mathbf{g} / \mathbf{d l})\end{array}$ & PCV (\%) & MCV (fl) & MCH (pg) & $\begin{array}{c}\text { MCHC } \\
\text { (g/dl) }\end{array}$ & P-value \\
\hline Subject & $3.1 \pm 0.7$ & 16.9 & $9.7 \pm 1.1$ & $32.7 \pm 0.3$ & $74.8 \pm 0.6$ & $26.9 \pm 0.9$ & $30.6 \pm 0.1$ & $<0.05$ \\
\hline Control & $4.3 \pm 0.6$ & 13.5 & $12.4 \pm 1.3$ & $37.0 \pm 0.2$ & $81 \pm 0.5$ & $27 \pm 0.4$ & $33 \pm 0.2$ & $<0.05$ \\
\hline
\end{tabular}

Table 3: Erythrocyte indices of control and experimental group of infants in Fufore IDP camp.

\section{Discussion}

The erythrocyte indices of children in IDP camp Yola have been analyzed, sex distribution of experimental subjects shows that, 160 (53.87\%) of children in camp were females while 137 (46.13\%) were males indicating the predominance of females' children over boys in Fufore IDP camp Yola. The mean total red cell count of children in camp was $3.1 \pm 0.7 \times 109 / 1$ while that of the control group was $4.3 \pm 0.7 \times 109 / 1$ this shows that infant in camp had a slightly lower red cell count than the control group at $\mathrm{P}<0.05$, and the PCV and hemoglobin level in subject was lower than that of the control group which could imply presence of asymptomatic anemia arising from inadequate erythropoietic process of several etiologies because in children, anemia is usually caused by decreased RBC production [10]. In addition, the RDW of infants in camp was $16.9 \%$ while the RDW for control group was $13.5 \%$ and this higher value of RDW among subjects is a pointer to anisocytosis in this group of children because RDW is a measure of the size variance of RBCs [11]. A low RDW suggests uniform red cell size, whereas an elevated RDW (greater than 14 percent) as observed in this study indicates RBCs of variable and multiple sizes (i.e anisocytosis) hence, the red cell of infants investigated were of variance sizes. The MCV of subjects was also lower than that of the control group and lower PCV in conjunction with low MCV together indicates present of microcytic anemia [12]. In addition the elevated RDW value combine with low MCV as observed in children in IDP camp in Yola is suggestive of iron deficiency anemia [13] and the implication of iron deficiency anemia is that, Iron deficiency (with or without anemia) have been reported to be associated with negative behavioral and cognitive defects in children[14,15] so that severe iron deficiency anemia is also associated with a lower intelligence quotient (IQ), diminished capability to learn, and suboptimal growth rate. Low red cell count, PCV and Hemoglobin value is indicative of anemia in children. Considering the relative available data obtain from analysis of erythrocyte indices of children in IDP camp in Yola, it can be inferred that infants in this camp may be living with microcytic and iron deficiency anemia asymptomatically. However, it has been documented that adequate intake of dietary iron can prevent iron deficiency anemia [16] and it consequences. On the other hand, there was no significant 
http://www.tridhascholars.org | July-2019

difference in values of $\mathrm{MCH}$ and $\mathrm{MCHC}$ of subjects and control group and this may indicate the absent of macrocytic anemia among children in IDP camp of Yola. This report goes to confirm with earlier medical literature that macrocytic anemia is rare in children [17].

\section{Conclusion}

In this present study, children in IDP camp have relatively lower RBC count, PCV, MCV, Hemoglobin values and high RDW value when compare to the control group at $\mathrm{P}<0.05$ and low MCV couple with low PCV indicates microcytic anemia while low MCV appearing with high RDW value is an indication for iron deficiency anemia. Therefore, microcytic and iron deficiency anemia was observed among children in Fufore IDP camp in Yola and children in this camp may require increased dietary iron intake or it supplement in other to prevent cognitive learning defect and suboptimal growth. It is believed that information obtained in this study will enhance adequate understanding of the healthcare need and anemic status of these group of children in Nigeria and more research on the nutritional and healthcare needs of children in IDP camps is advocated.

\section{Financial Sponsorship}

The study was not sponsored, the equipment used was provided by the hospital in which this work was done.

\section{Acknowledgment}

The authors are sincerely grateful to the management of Federal Medical Center Yola, for providing the environment and equipment for this research work.

\section{References}

1. Akodu SO, Njokanma OF, AdeoluKehinde O (2015) Erythrocyte indices in pre-school Nigerian children with sickle cell anaemia in steady state. International Journal of Hematology-oncology and Stem Cell Research 9(1): 5-9.

2. Emmanuel Asuquo Etim (2018) Effect of maintenance hemodialysis on red cell indices and erythrocyte sedimentation rate in Northeast Nigeria. ARC Journal of Hematology 3(1): 17-22.

3. Ositadinma IM, Ikponmwosa OS, Okechukwu OC (2015) Hematology and red cell indices in HIV positive individuals on anti-retroviral therapy in Delta State, Nigeria. International Journal of Current Research and Review 7(12): 24-30.

4. Terri A, Cavaliere MS (2004) Newborn and Infant Nursing Reviews. Journal Hematological Disorders 4(4): 321 -329.

5. OXFAM (2014) Assessment of Escalating Humanitarian Needs Due to Increased Influx of IDPs into Yola and its Environs. Yola: OXFAM.

6. International Rescue Committee (IRC) (2014) Multi-Sectoral Humanitarian Needs Assessment in North Eastern Nigeria. Yola: IRC.

7. International Organisation for Migration (IOM) (2015) DTM Nigeria Report Round IV. Abuja: International Organisation for Migration (IOM).

8. INGO FORUM in Nigeria (2015) Humanitarian Situation in North Eastern Nigeria. Abuja: INGO FORUM in Nigeria.

9. Buseri FI, Siaminabo IJ, Jeremiah ZA (2010) Reference value of hematological indices of infants, Children, and adolescents in Port Harcourt, Nigeria. Pathology and Laboratory Medicine 2: 65-70.

10. Irwin JJ, Kirchner JT (2001) Anemia in children. American Family Physician 64(8): 1379-1386.

11. Pediatric Nutrition Handbook (2009) ( $6^{\text {th }}$ Edn) Elk Grove Village, Ill.: American Academy of Pediatrics 403-422.

12. Jenifer Janus, Sarah Moerschel (2010) Evaluation of anemia in children. American Family Physician 81(12): 1462-1471. 
http://www.tridhascholars.org | July-2019

13. Olhs RK, Christensen RD (2004) Diseases of the blood. In: Behrman RE, Kliegman R, Jenson HB (Eds.) Nelson Textbook of Pediatrics. 17 $7^{\text {th }}$ (Edn.) Philadelphia, Pa: Saunders 1604-1634.

14. McCann JC, Ames BN (2007) An overview of evidence for a causal relation between iron deficiency during development and deficits in cognitive or behavioral function. The American Journal of Clinical Nutrition 85(4): 931-945.

15. Beard JL (2008) Why iron deficiency is important in infant development. Journal of Nutrition 138(12): 2534-2536.

16. American Academy of Pediatrics Committee on Nutrition (1992) The use of whole cow's milk in infancy. Pediatrics 89(6.1): 1105-1109.

17. Davenport J (1996) Macrocytic anemia. American Family Physician 53(1): 155-162. 